\title{
Sheep performance on perennial ryegrass cultivars differing in concentration of water-soluble carbohydrate
}

\author{
G.P. COSGROVE, P.S. TAYLOR and A. JONKER \\ AgResearch Grasslands, PB 11008, Palmerston North 4442 \\ gerald.cosgrove@agresearch.co.nz
}

\begin{abstract}
High-sugar perennial ryegrass cultivars (HSG) selected for higher concentrations of water-soluble carbohydrate may enhance animal production and reduce emissions of methane and nitrogen. Assessing the effects on economic output and environmental footprint is most robust when related to production per unit of land. Average daily gain (ADG) and liveweight gain per hectare (LWG/ha) of sheep grazing a high-sugar perennial ryegrass cultivar, a diploid perennial ryegrass and a tetraploid perennial ryegrass were compared during measurement periods conducted in spring ( 84 days duration), autumn (99 days) and late springsummer (160 days). Continuous variable stocking was used, and stocking rate adjusted to maintain a target sward surface height of $6 \mathrm{~cm}$. Average daily gain was higher $(\mathrm{P}=0.003)$ on the HSG than on either control in late spring-summer and higher on the tetraploid control than on the HSG or the diploid control in autumn $(\mathrm{P}=0.04)$, but the higher ADGs did not translate to significantly higher LWG/ha. These results can inform farmers on cultivar choice and support analysis of methane and nitrogen emissions on an intensity basis for inventory and regulatory purposes.
\end{abstract}

Key words: water-soluble carbohydrate, perennial ryegrasses, high-sugar ryegrass, average daily gain, liveweight gain

\section{Introduction}

High sugar ryegrasses (HSGs), bred for elevated concentrations of water-soluble carbohydrate (WSC; sugar) can increase sheep liveweight gain (Munro et al. 1992; Lee et al. 2001; Proctor et al. 2015), milk production (Cosgrove et al. 2007; Miller et al. 2001b) and improve the utilisation of dietary protein, thereby reducing nitrogen excretion (Miller et al. 2001a; Pacheco et al. 2007, 2009). However, there are also studies which show no animal response (Cosgrove et al. 2007; Marley et al. 2007; Tas et al. 2006; Taweel et al. 2006 ), and recent reviews highlight the uncertain efficacy of elevated WSC (Edwards et al. 2007; Parsons et al. 2011). An important measure of the efficacy of this trait, especially economic performance, is animal production per unit area of land. This takes into account pasture production, dry matter intake and nutritive value, and conversion to animal product. To date, New Zealand studies on HSGs have focussed on measuring the effects on animal productivity and/or environmental impact at the level of the individual sheep (Proctor et al. 2015) or cow (Cosgrove et al. 2007). While studies conducted in the United Kingdom have measured responses to higher levels of WSC in terms of sheep production per hectare (Munro et al. 1992; Lee et al. 2001; Marley et al. 2007), the authors are not aware of studies in New Zealand conducted on the same basis.

Recent data from the United Kingdom (DEFRA 2010) and New Zealand (Jonker et al. 2014) suggests that the high-sugar trait may also reduce methane emissions. In order to scale-up the effects of grass cultivar on methane emissions measured per individual animal ( $\mathrm{g} \mathrm{CH}_{4} /$ head/day) to an intensity basis (i.e. $\mathrm{g} \mathrm{CH}_{4}$ per hectare of land, or per unit of animal production) for inventory or regulatory purposes, it is necessary to measure all aspects of animal performance in conjunction with measurements of methane emissions. This paper reports a study conducted to measure the effects of grass cultivar on performance per animal and per hectare under New Zealand conditions, and to support the interpretation of associated measurements on methane emissions. The hypothesis tested was that ryegrasses selected for a higher concentration of WSC would increase sheep average daily gain (ADG) and liveweight gain per hectare (LWG/ha).

\section{Materials and Methods}

Site

This grazing trial with sheep was conducted at the AgResearch Aorangi Research Farm, Manawatu, on Kairanga and Te Arakura recent alluvial soils (Rijkse \& Daly 1972). Measurement periods were conducted during spring 2013 (26 September-18 December; 84 days), autumn and early winter 2014 (22 April-30 July; 99 days; henceforth referred to as autumn) and late-spring, summer and early-autumn 2014/15 (25 November-4 May; 160 days; henceforth referred to as late spring-summer). The latter period was interrupted by drought in January (11 mm rainfall compared with the 20 -year mean of $65 \mathrm{~mm}$ ), and all sheep were removed from plots for 2 weeks in February because sward surface height (SSH) declined below the target height of $6 \mathrm{~cm}$ (see description under Measurements below). Following 
removal, sheep were held for 1 week as a single group on non-trial grass pasture, and then separated again into their respective treatment groups (replicate groups within treatment still combined) and given 1 week on spare plots for readaptation to their assigned cultivar before being returned to treatment plots.

\section{Experimental treatments and design}

Three cultivars of perennial ryegrass, each containing AR1 endophyte, were compared: a high-sugar diploid perennial ryegrass (cv. 'Abermagic'; flowering date +15 days compared with 'Nui'), a control diploid perennial ryegrass (cv. 'Alto'; +14 days) and a control tetraploid perennial ryegrass (cv. 'Base', +25 days). The design consisted of a randomised complete block, with four replicate blocks. Across blocks, plots ranged in size from 0.56 to 0.67 ha, but within blocks the plots of each cultivar were identical in size. Each cultivar was sown in monoculture into a cultivated seedbed in autumn 2013. Diploid cultivars were sown at $20 \mathrm{~kg}$ $\mathrm{seed} / \mathrm{ha}$ and the tetraploid at $28 \mathrm{~kg}$ seed $/ \mathrm{ha}$.

\section{Soil and pasture management}

Pastures were fertilised after sowing with $250 \mathrm{~kg} / \mathrm{ha}$ of Cropmaster 15 (Ravensdown Ltd.; 15\% N, 10\% $\mathrm{P}, 10 \% \mathrm{~K}, 8 \% \mathrm{~S}$ ) in May 2013, and with $300 \mathrm{~kg} / \mathrm{ha}$ superphosphate $(9 \% \mathrm{P}, 11 \% \mathrm{~S})$ in July 2013 , as part of farm fertiliser policy for Aorangi. A soil test taken in October 2013 indicated pH 5.6 and Olsen-P of 31. Lime was applied at $2.5 \mathrm{t} / \mathrm{ha}$ in February 2014 to correct the low $\mathrm{pH}$. Nitrogen fertiliser was applied at $75 \mathrm{~kg}$ urea/ha 2-3 times during each grazing period. Between grazing periods, plots were stocked with sheep and occasionally cattle, to maintain the continuously-stocked sward state.

\section{Animals}

For measurements in spring 2013, 120 one-year-old ewes were used $(42.0 \pm 3.33 \mathrm{~kg}$ initial liveweight $(\mathrm{LW}))$; in autumn 2014120 6-month-old cryptorchid lambs $(30.7 \pm 1.37 \mathrm{~kg} \mathrm{LW})$ and in late spring-summer 2014/15 1803 -month-old newly weaned cryptorchid lambs were used $(28.7 \pm 1.53 \mathrm{~kg} \mathrm{LW})$. For each season sheep were weighed and allocated to 12 groups ( $\mathrm{n}=10$ for spring and autumn and $\mathrm{n}=15$ for late spring-summer), with each group having the same mean and range in LW. In each season an additional pool of cohorts from the same flock was identified, from which put-and-take grazers could be drawn (described below). These experiments were conducted under AgResearch Grasslands Animal Ethics Committee approvals \#13004 and \#13385.

\section{Trial stocking management}

A continuous, variable stocking method was used. For spring 2013 and autumn 2014 each plot was stocked with 10 "tester" sheep, and 15 sheep for late spring- summer 2014/15, on which measurements of ADG were based. In addition, a variable number of "putand-take" (P\&T) sheep were used. Decisions to add or remove $\mathrm{P} \& \mathrm{~T}$ animals were based on changes in $\mathrm{SSH}$ from the target of $6 \mathrm{~cm}$. Liveweight gain/ha for the grazing period was calculated from the total number of grazing days (total number of sheep each day $\times$ number of days) $\times$ ADG of the tester sheep. For late springsummer 2014/15, 15-month-old heifers $(346 \pm 13.4 \mathrm{~kg}$ LW) were used as P\&T grazers in addition to sheep to give greater capacity to control SSH during the period of high pasture accumulation rates when ryegrasses were flowering. Each heifer was considered equivalent to 5 lambs for calculating grazing days and LWG per ha, based on the ratio of stock units (s.u.) for each species (heifers 4.5 s.u. and lambs 0.9 s.u.; Woodford \& Nicol 2004). Overall, heifers accounted for $15 \%$ of total grazing days and lambs $85 \%$. This proportion was similar for each cultivar and replicate, so the assumption of 1 heifer $=5$ lambs was considered unlikely to have biased the calculation of LWG/ha.

\section{Measurements}

Pasture: Sward surface heights were recorded by taking 25 readings per plot twice weekly using a Hill Farming Research Organisation sward stick (see Frame (1993) for description of methodology). To collect representative samples of the herbage offered, three (four in late spring-summer 2014/15) grazing exclosure cages $(1.0 \times 0.5 \mathrm{~m})$ were randomly placed in each plot and after 2 weeks herbage accumulation in spring and 3-4 weeks in autumn (and one interval of 5 weeks in summer 2015) a sample was cut to the mean SSH of that plot recorded when the cage was placed. After each sampling each cage was relocated to a new site within the plot (no pre-trimming). The sample from each cage was composited into a single sample for the plot and immediately frozen in liquid nitrogen and stored frozen. Samples were subsequently freeze dried, ground to pass a $1 \mathrm{~mm}$ sieve and analysed using near-infrared reflectance spectroscopy (FeedTECH, AgResearch Grasslands, Palmerston North) to predict concentrations of water-soluble carbohydrates (calibrated using the anthrone method (Thomas 1977)), crude protein (CP), neutral detergent fibre (NDF) and organic matter digestibility. These samples were collected six times during spring 2013, five times during autumn 2014, and seven times during late spring-summer 2014/15. Samples from each time point were analysed separately and the season mean concentrations presented.

Animal: After 1 week of adaptation to grazing the assigned cultivar the sheep were weighed again directly off pasture (full liveweight (LW)). At the end of the grazing period full LW was again recorded. Average 
daily gain was calculated from liveweight gain over the period excluding adaptation, and for late springsummer 2014/15 included the 2-week period when drought forced the removal of lambs from plots.

\section{Data analysis}

The experimental unit was the plot and the group of animals grazing on it. Data was analysed for each season separately. Cultivar effects for pasture and animal variables ( 2 d.f.) were compared using analysis of variance, with the cultivar $\times$ block interaction $(6$ d.f.) used as error term after removing block effects ( 3 d.f.). Comparison of means is based on Fisher's protected least significant difference at $\mathrm{P}<0.05$.

\section{Results}

\section{Sward surface height}

During spring 2013 each cultivar was maintained at a similar SSH, although SSH was marginally below the target of $6 \mathrm{~cm}$ during October and increased above the target from early November, and particularly so during December (Figure 1a). In autumn 2014, the tetraploid control had a lower SSH than the other two cultivars during May, but from then on all three cultivars were above the target until the termination in late July (Figure 1b). For late spring-summer 2014/2015, cultivars were similar in SSH until early February, although SSH had declined to $4 \mathrm{~cm}$ when lambs were temporarily removed (Figure 1c). Plots recovered to $7 \mathrm{~cm} \mathrm{SSH}$ during spelling, but the tetraploid control again had lower SSH than the other cultivars during March, yet recovered to be similar to the other cultivars by the end of April.

\section{Ryegrass chemical composition}

In spring 2013 the cultivars did not differ significantly in concentrations of WSC or CP, but the HSG and the tetraploid control were lower in NDF than the diploid control (Table 1). In autumn 2014 the HSG had a significantly higher concentration of WSC $(\mathrm{P}=0.009)$ and significantly lower concentration of $\mathrm{CP}(\mathrm{P}=0.02)$ than either of the control cultivars and had a lower concentration of NDF $(\mathrm{P}=0.001)$ compared with the diploid control. In late spring-summer 2014/2015, the HSG had a higher concentration of WSC $(\mathrm{P}=0.017)$ and lower concentration of NDF ( $\mathrm{P}=0.0004)$, than either of the control cultivars.

\section{Animal performance}

There were no significant differences among cultivars in sheep ADG (mean of $164 \mathrm{~g} / \mathrm{hd} /$ day) or in LWG/ha (427 kg LWG/ha) in spring 2013 (Table 2). In autumn 2014, lambs grazing the tetraploid control had higher ADG (206 g/day) compared with those grazing the HSG or diploid control (179 g/day; $\mathrm{P}=0.04)$, but this was offset by lower stocking rate (data not shown),
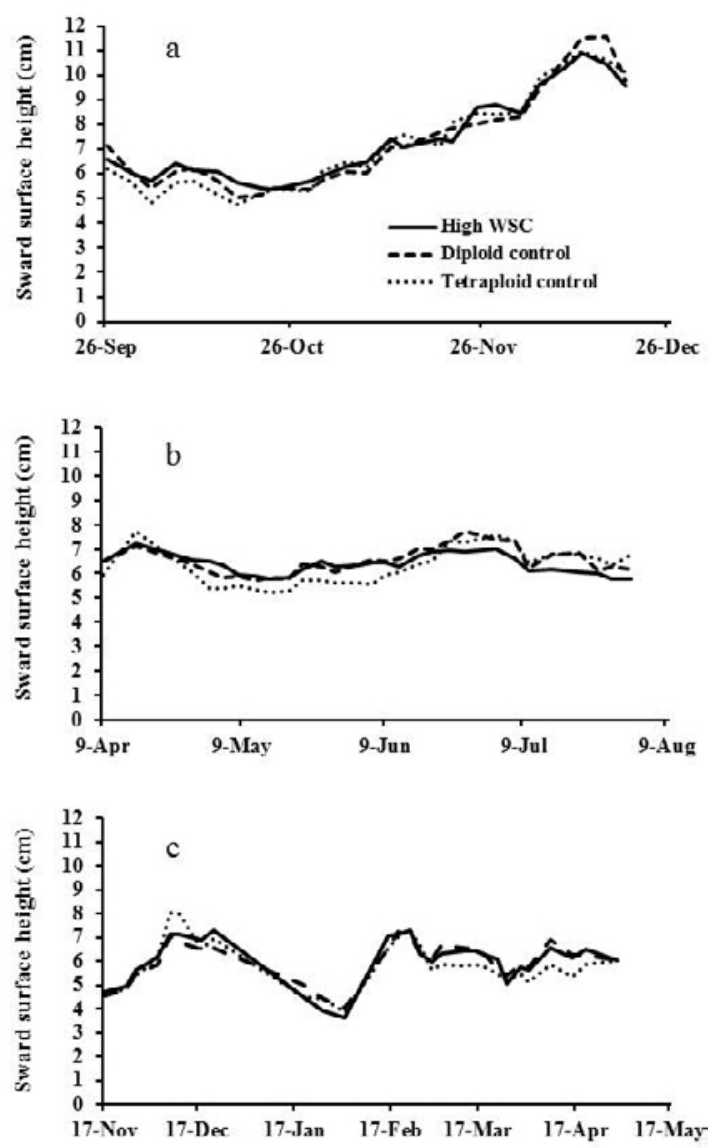

Figure 1 The sward surface height of three cultivars of perennial ryegrass, a diploid high water-soluble carbohydrate (WSC) cultivar, a diploid control cultivar and a tetraploid control cultivar, under continuous variable stocking by sheep during measurement periods in spring 2013 (a), autumn 2014 (b) and late spring-summer 2014/15 (c).

such that LWG/ha did not differ among cultivars (mean $335 \mathrm{~kg} / \mathrm{ha}$ ). In late spring-summer 2014/15, ADG was higher $(\mathrm{P}=0.003)$ for sheep grazing the HSG (133 g/ day) than for either of the control cultivars (mean of $119 \mathrm{~g} /$ day), but this did not translate to significantly higher LWG/ha.

\section{Discussion}

Average daily gain was influenced by ryegrass cultivar in two of the three periods of measurement in this study but in one case sheep grazing the tetraploid control had the highest ADG and in the other case sheep grazing the HSG had the highest ADG. These effects did not translate to significantly higher LWG/ha. Some studies conducted in the United Kingdom with sheep similarly continuously stocked on monoculture swards maintained at a SSH of 6-7 cm (Munro et al. 1992; 
Lee et al. 2001) have reported higher ADG and LWG/ ha on a high-WSC cultivar compared with a control, but others have recorded no difference (Marley et al. 2007). Munro et al. (1992) reported 19\% higher lamb LWG/ha from the high-WSC cultivar which they attributed to higher organic matter digestibility because herbage production was similar for each cultivar (concentrations of WSC were not reported). The study by Lee et al. (2001) recorded ADG of lambs up to $25 \%$ higher and LWG/ha up to $35 \%$ higher when grazing the experimental line high-WSC ryegrass in two out of three measurement periods, which they attributed to a combination of higher WSC and lower structural fibre in the high-WSC ryegrass. Proctor et al. (2015) also reported higher ADG from a high-WSC compared with a control cultivar when each was growing in mixture with white clover, but did not report the proportions of each species in the mixture. It is possible that differences between the high-WSC and the control pastures in the proportions of ryegrass and white clover may have influenced the cultivar comparison, as was demonstrated in the study by Munro et al. (1992). In the study by Lee et al. (2001) the differences between the high-WSC ryegrass and control cultivar in concentrations of WSC (up to $54 \mathrm{~g} \mathrm{WSC} / \mathrm{kg}$ DM higher in the high-WSC grass) and NDF (up to $76 \mathrm{~g} \mathrm{NDF} / \mathrm{kg}$ DM lower in the high-

Table 1 The effects of three cultivars of perennial ryegrass, a diploid high water-soluble carbohydrate (WSC) cultivar, a diploid control cultivar and a tetraploid control cultivar, on the mean concentrations (g/kg DM) of WSC, crude protein (CP) and neutral detergent fibre (NDF) during measurements periods in spring 2013, autumn 2014 and late spring-summer 2014/15.

\begin{tabular}{|c|c|c|c|c|c|c|}
\hline \multirow[t]{2}{*}{ Season } & \multirow[t]{2}{*}{ Item } & \multicolumn{3}{|c|}{ Ryegrass cultivar } & \multirow[t]{2}{*}{$\mathbf{P}_{0.05}$} & \multirow[t]{2}{*}{$\mathrm{LSD}_{0.05}$} \\
\hline & & $\begin{array}{l}\text { High } \\
\text { WSC }\end{array}$ & $\begin{array}{l}\text { Diploid } \\
\text { control }\end{array}$ & $\begin{array}{c}\text { Tetraploid } \\
\text { control }\end{array}$ & & \\
\hline \multirow[t]{3}{*}{ Spring 2013} & WSC & 196 & 182 & 178 & 0.71 & 29.4 \\
\hline & $\mathrm{CP}$ & 216 & 213 & 225 & 0.68 & 33.3 \\
\hline & NDF & $434 b^{1}$ & $458 a$ & $440 \mathrm{~b}$ & 0.02 & 15.0 \\
\hline \multirow[t]{3}{*}{ Autumn 2014} & WSC & $186 a$ & $155 b$ & $162 b$ & 0.009 & 10.5 \\
\hline & $\mathrm{CP}$ & $252 b$ & $267 a$ & $274 a$ & 0.02 & 13.7 \\
\hline & NDF & $416 b$ & $439 a$ & $416 b$ & 0.001 & 14.8 \\
\hline Late spring- & WSC & $251 a$ & $221 b$ & $213 b$ & 0.017 & 24.3 \\
\hline \multirow[t]{2}{*}{ summer 2014/15 } & $\mathrm{CP}$ & 175 & 177 & 189 & 0.100 & 14.2 \\
\hline & NDF & $462 c$ & $497 a$ & $485 b$ & 0.0004 & 10.1 \\
\hline
\end{tabular}

${ }^{1}$ Means within row followed by different letters differ significantly $\mathrm{P}<0.05$

Table 2 The effects of three cultivars of perennial ryegrass, a diploid high water-soluble carbohydrate (WSC) cultivar, a diploid control cultivar and a tetraploid control cultivar, on average daily gain (ADG; g/day) and liveweight gain per hectare (LWG/ha; kg/ha) of sheep during measurements periods in spring 2013, autumn 2014 and late spring-summer 2014/15.

\begin{tabular}{|c|c|c|c|c|c|c|}
\hline \multirow[t]{2}{*}{ Season } & \multirow[t]{2}{*}{ Item } & \multicolumn{3}{|c|}{ Ryegrass cultivar } & \multirow[t]{2}{*}{$\mathbf{P}_{0.05}$} & \multirow[t]{2}{*}{$\operatorname{LSD}_{0.05}$} \\
\hline & & $\begin{array}{l}\text { High } \\
\text { WSC }\end{array}$ & $\begin{array}{l}\text { Diploid } \\
\text { control }\end{array}$ & $\begin{array}{c}\text { Tetraploid } \\
\text { control }\end{array}$ & & \\
\hline \multirow[t]{2}{*}{ Spring 2013} & ADG & 170 & 158 & 164 & 0.62 & 37.3 \\
\hline & LWG/ha & 478 & 381 & 421 & 0.17 & 108.3 \\
\hline \multirow[t]{2}{*}{ Autumn 2014} & ADG & $179 b^{1}$ & $179 b$ & $206 a$ & 0.04 & 22.8 \\
\hline & LWG/ha & 329 & 339 & 337 & 0.89 & 55.2 \\
\hline Late spring- & ADG & $133 a$ & $120 b$ & $118 b$ & 0.003 & 6.7 \\
\hline summer $2014 / 15$ & LWG/ha & 500 & 434 & 446 & 0.28 & 97.6 \\
\hline
\end{tabular}

${ }^{1}$ Means within row followed by different letters differ significantly $\mathrm{P}<0.05$ 
WSC grass) were approximately double the magnitude of differences in the study reported here. In the study by Marley et al. (2007) where no animal response was noted, the difference between cultivars in concentration of WSC was only $11 \mathrm{~g} \mathrm{WSC} / \mathrm{kg} \mathrm{DM}$. While expression of higher WSC in the ryegrass selected for high-WSC largely determines the magnitude of this difference, the choice of control cultivar(s) may also influence the difference and whether or not a significant animal response is observed. The study reported here and those by Lee et al. (2001) and Proctor et al. (2015) each used a different high-WSC cultivar and a different control cultivar. Cultivars used as controls, while not selectively bred on the basis of WSC, can differ among themselves in the concentrations of WSC (Easton et al. 2009). Cultivar choice, as well as environmental effects on WSC concentrations and expression of the highWSC trait in an HSG (Cosgrove et al. 2014; Parsons et al. 2004), should all be considered in comparisons among studies.

Sward physical conditions were controlled as tightly as practicable to minimise limitations to dry matter intake (DMI), with some possible exceptions as discussed below. Of all sward characteristics SSH has a predominant influence on DMI by grazing animals. Maintaining swards at or above $6 \mathrm{~cm} \mathrm{SSH}$ is considered to be non-limiting to DMI (Penning et al. 1991) and maintaining this target height was the primary measure for ensuring uniformity of feeding conditions across cultivars and across seasons. There were occasions when SSH was lower than the target when adjustments to stocking rate were not fast enough or great enough, and so possibly limiting to DMI. The DMI of sheep grazing the tetraploid control may have been restricted in autumn 2014 when the SSH was below $6 \mathrm{~cm}$ for approximately 30 days of the 99 day duration. Even so, sheep are remarkably flexible in their ingestive behaviour (e.g., biting and chewing behaviour) and the time they spend grazing each day, and restrictions in say bite mass because of low SSH can be compensated by increases in the time spent grazing to satisfy their DMI requirement. Exceeding the target SSH is unlikely to affect DMI in the short-term (in the longer-term sward quality would deteriorate), but it indicates stocking rate was lower than the swards could support and so the potential LWG/ha may have been underestimated. In this latter case when SSH exceeded the target all cultivars were similar in height and so unlikely to have biased the comparison among cultivars in LWG/ha.

Comparisons among cultivars in nutritive value, expressed through ADG, and herbage accumulation rates, expressed through LWG/ha, were the experimental variables of primary interest in this study. A greater concentration of WSC in herbage may increase nutritive value but this effect is influenced by the changes in concentrations of other constituents. For example, if a greater concentration of WSC is offset by a lower concentration of structural carbohydrates this can lead to higher DMI, and so greater ADG (Lee et al. 2001), and if crude protein is low, the greater concentration of WSC can improve microbial protein capture in the rumen and so improve overall protein nutrition (Kingston-Smith \& Theodorou 2000). The concentration of WSC was higher in the HSG than in the diploid control by 14-31 g WSC/kg DM, a difference comparable with some New Zealand studies conducted under cutting (Hume et al. 2010) or sheep grazing (Parsons et al. 2004), but lower than the additional 35$47 \mathrm{~g} \mathrm{WSC} / \mathrm{kg} \mathrm{DM}$ in rotationally grazed dairy pastures at four sites differing in latitude (Cosgrove et al. 2014). While cultivars did not differ significantly in WSC (or CP) in spring 2013 (a possible explanation for this is discussed below), the significantly lower concentration of NDF in the high-WSC ryegrass is consistent with the expected difference in chemical composition of that compared with a control, and as the concentration of one constituent increases the concentration of others inevitably decreases (Cosgrove et al. 2009; Rasmussen et al. 2009). Within season there did not appear to be a consistent relationship between a greater concentration of WSC and greater ADG. However, the associated changes in NDF and CP may also have influenced the observed ADG response, as modelling studies have suggested for nitrogen emissions and milk yield (Ellis et al. 2011). In each season the concentration of $\mathrm{CP}$ in each of the three cultivars was above the recommended minimum level for growing sheep (National Research Council 2007), and so ADG would be more likely to have been affected by differences in WSC and NDF than by differences in CP. Given the uncertain response to the aggregate effect of an increase in the concentration of WSC and a decrease in NDF, digestibility may be a simpler explanatory variable for assessing overall trends. Across cultivars and seasons, there was a clear, positive relationship between ADG and organic matter digestibility $\left(\mathrm{R}^{2}=0.68\right.$; Figure 2 ), although even this does not fully account for the observed ADGs. Overall, ADG increased by $0.5 \mathrm{~g} /$ day for each $1 \mathrm{~g} / \mathrm{kg}$ DM increase in organic matter digestibility. Choosing cultivars selected for high WSC, or tetraploid cultivars, which also achieve higher organic matter digestibility, regardless of whether that results from a greater concentration of WSC or from a lower concentration of NDF, can be expected to result in higher daily gains. Other factors such as seasonal growing conditions that result in favourable chemical composition and higher organic matter digestibility will also increase daily gains. Higher WSC specifically, may be important when the herbage $\mathrm{CP}$ concentration is low, because under those conditions the additional 


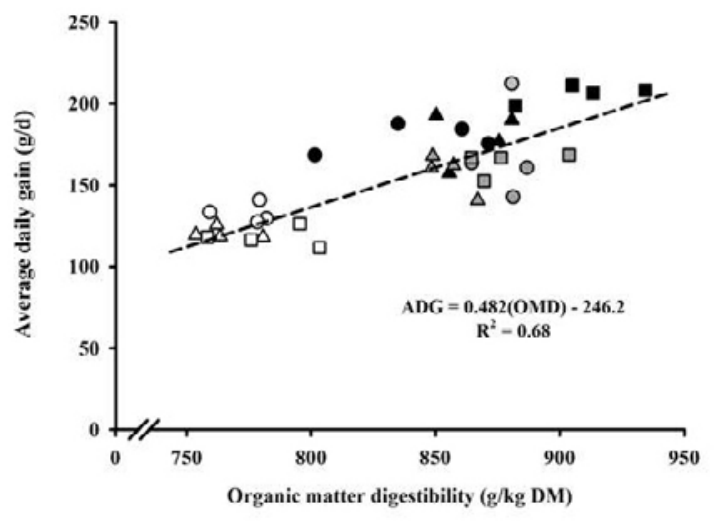

Figure 2 The relationship between organic matter digestibility of three cultivars of perennial ryegrass, a diploid high water-soluble carbohydrate (WSC) cultivar (circles), a diploid control cultivar (triangles) and a tetraploid control cultivar (squares) and average daily gains of sheep grazing those cultivars during measurement periods in spring 2013 (grey symbols), autumn 2014 (solid symbols) and late spring-summer 2014/15 (open symbols).

WSC improves ruminal protein utilisation and so the availability of protein for liveweight gain.

For spring 2013, when the difference among cultivars in WSC or CP was not significant, variability among replicate blocks was high, particularly the variability among the six sampling dates underlying the season mean for cultivars within one replicate. There is no clear reason for this, but the replicate in question had been spelled from grazing during August to accumulate herbage of each cultivar tall enough to mechanically harvest in September for a related indoor feeding trial (Jonker et al. 2014). It is possible that this management practice affected herbage chemical composition as the swards recovered from severe defoliation at harvest and progressively readjusted to a short, leafy, continuously stocked state.

\section{Conclusions}

The average daily gain was highest for lambs grazing the HSG in one measurement period, consistent with the hypothesised effect of a greater concentration of WSC. However, the highest ADG for the tetraploid control in another measurement period could not be explained on this basis alone. There was a positive relationship of ADG with organic matter digestibility and factors which increase organic matter digestibility, which includes cultivar attributes such as high WSC and tetraploidy, will enhance ADG. Cultivar effects resulting in higher $\mathrm{ADG}$ did not translate to higher LWG/ha. Specifically, these results will inform the assessment of methane emissions on an intensity basis to determine the mitigation potential of high-sugar ryegrasses. More generally, they can be used by farmers to inform cultivar selection in lamb grazing systems.

\section{ACKNOWLEDGEMENTS}

This project was funded from the Sustainable Land Management and Climate Change Fund administered by the Ministry for Primary Industries. Thanks to Steve Lees, Richard Templeton and Derek Birch of the Aorangi Research Farm for managing the stocking rate adjustments and animal measurements, to Fiona Smith and Tara Hancock for assisting with pasture measurements, and to David Pacheco for discussions on data interpretation.

\section{REFERENCES}

Cosgrove, G.P.; Burke, J.L.; Death, A.F.; Hickey, M.J.; Pacheco, D.; Lane, G.A. 2007. Ryegrasses with increased water-soluble carbohydrate: evaluating the potential for grazing dairy cows in New Zealand. Proceedings of the New Zealand Grassland Association 69: 179-185.

Cosgrove, G.P.; Koolaard, J.; Luo, D.; Burke, J.L.; Pacheco, D. 2009. The composition of high sugar ryegrasses. Proceedings of the New Zealand Grassland Association 71: 187-193.

Cosgrove, G.P.; Mapp, N.R.; Taylor, P.S.; Harvey, B.M.; Knowler, K.J. 2014. The chemical composition of high-sugar and control ryegrasses in grazed pastures at different latitudes throughout New Zealand. Proceedings of the New Zealand Grassland Association 76: 169-175.

DEFRA. 2010. Ruminant nutrition regimes to reduce methane and nitrogen emissions. Final Report AC0209, Department for Environment Food \& Rural Affairs. 37 pp.

Easton, H.S.; Stewart, A.V.; Lyons, T.B.; Parris, M.; Charrier, S. 2009. Soluble carbohydrate content of ryegrass cultivars. Proceedings of the New Zealand Grassland Association 71: 161-166.

Edwards, G.R.; Parsons, A.J.; Rasmussen, S. 2007. High sugar ryegrasses for dairy systems. pp. 307-334. In: Meeting the challenges for pasture-based dairying. Proceedings of the 3rd Dairy Science Symposium. Eds. Chapman, D.F.; Clark, D.A.; Macmillan, K.L.; Nation, D.P. 18-20 September 2007, University of Melbourne, Victoria, Australia. Published by the National Dairy Alliance.

Ellis, J.L.; Dijkstra, J.; Bannik, A.; Parsons, A.J.; Rasmussen, S.; Edwards, G.R. 2011. The effect of high sugar grass on predicted nitrogen emission and milk yield simulated using a dynamic model. Journal of Dairy Science 94: 3105-3118.

Frame, J. 1993. Herbage mass. Chapter 3. In: Sward measurement handbook, 2nd Edition. Eds. Davies, A.; Baker, R.D.; Grant, S. A.; Laidlaw, A.S. British Grassland Society, University of Reading, UK. 
Hume, D.E.; Hickey, M.J.; Lyons, T.B.; Baird, D.B. 2010. Agronomic performance and water soluble carbohydrate expression of selected ryegrasses at two locations in New Zealand. New Zealand Journal of Agricultural Research 53: 37-57.

Jonker, A.J.; Molano, G.; Sandoval, E.; Taylor, P.S.; Antwi, C.; Cosgrove, G.P. 2014. Methane emissions by sheep offered high sugar or conventional perennial ryegrass at two allowances. Proceedings of the New Zealand Society of Animal Production 74: 145-147.

Kingston-Smith, A.H.; Theodorou, M.K. 2000. Post-ingestion metabolism of fresh forage. New Phytologist 148: 37-55.

Lee, M.R.F.; Jones, E.L.; Moorby, J.M.; Humphreys, M.O; Theodorou, M.K.; MacRae, J.C.; Scollan, N.D. 2001. Production response from lambs grazed on Lolium perenne selected for an elevated water soluble carbohydrate concentration. Animal Research 50: 441-449.

Marley, C.L.; Fraser, M.D.; Fisher, W.J.; Forbes, A.B.; Jones, R.; Moorby, J.M.; MacRae, J.C.; Theodorou, M.K. 2007. Effects of continuous or rotational grazing of two perennial ryegrass varieties on the chemical composition of the herbage and the performance of finishing lambs. Grass and Forage Science 62: 255-264.

Miller, L.A.; Baker, D.H.; Theodorou, M.K.; MacRae, J.C.; Humphreys, M.O.; Scollan, N.D.; Moorby, J.M. 2001a. Efficiency of nitrogen use in dairy cows grazing ryegrass with different water soluble carbohydrate concentrations. pp. 377-378. In: Proceedings XIX International Grasslands Congress. Sao Paulo, Brazil. Eds. Gomide, J.A.; Mattos, W.R.M.; da Silva, S.C.

Miller, L.A.; Moorby, J.M.; Davies, D.R.; Humphreys, M.O.; Scollan, N.D.; MacRae, J.C.; Theodorou, M.K. 2001b. Increased concentration of water-soluble carbohydrate in perennial ryegrass (Lolium perenne L.): milk production from late-lactation dairy cows. Grass and Forage Science 56: 383-394.

Munro, J.M.M.; Davies, D.A.; Evans, W.B.; Scurlock, R.V. 1992. Animal production evaluation of herbage varieties. 1. Comparison of Aurora with Frances, Talbot and Melle perennial ryegrasses when grown alone and with clover. Grass and Forage Science 47: 259-273.

National Research Council. 2007. Nutrient requirements of small ruminants: sheep, goats, cervids and new world camelids. Animal Nutrition Series. National Research Council of the National Academies. The National Academies Press, Washington, DC.

Pacheco, D.; Burke, J.L.; Cosgrove, G.P. 2007. An empirical model to estimate efficiency of nitrogen utilisation in cows grazing fresh forages. pp. 409416. In: Meeting the challenges for pasture-based dairying. Proceedings of the 3rd Dairy Science Symposium. Eds. Chapman, D.F.; Clark, D.A.; Macmillan, K.L.; Nation, D.P. 18-20 September 2007, University of Melbourne, Victoria, Australia. Published by the National Dairy Alliance.

Pacheco, D.; Lowe, K.; Burke, J.L.; Cosgrove, G.P. 2009. Urinary nitrogen excretion from cows at different stage of lactation grazing different ryegrass cultivars during spring or autumn. Proceedings of the New Zealand Society of Animal Production 69: 196200.

Parsons, A.J.; Rasmussen, S.; Xue, H.; Newman, J.A.; Anderson, C.B.; Cosgrove, G.P. 2004. Some 'high sugar grasses' don't like it hot. Proceedings of the New Zealand Grassland Association 66: 265-271.

Parsons, A.J.; Rowarth, J.S.; Rasmussen, S. 2011. High-sugar grasses. CAB Reviews: Perspectives in Agriculture, Veterinary Science, Nutrition and Natural Resources. 6: 1-12.

Penning, P.D. Parsons, A.J.; Orr, R.J.; Treacher, T.T. 1991. Intake and behaviour responses by sheep to changes in sward characteristics under continuous stocking. Grass and Forage Science 46: 15-28.

Proctor, L.E.; Craig, H.J.B.; Mclean, N.J.; Fennessy, P.F.; Chuah, J.; Campbell, A.W. 2015. The effect of grazing high sugar grass on lamb performance. Proceedings of the New Zealand Society of Animal Production 75: 235-238.

Rasmussen, S.; Parsons, A.J.; Xue, H.; Newman, J.A. 2009. High sugar grasses: harnessing the benefit of new cultivars through growth management. Proceedings of the New Zealand Grassland Association 71: 167-175.

Rijkse, W.C.; Daly. B.K. 1972. Soils of the Aorangi experimental farm. New Zealand Journal of Agricultural Research 15: 117-136.

Tas, B.M.; Taweel, H.Z.; Smit, H.J.; Elgersma, A.; Dijkstra, J.; Tamminga, S. 2006. Effects of perennial ryegrass cultivars on milk yield and nitrogen utilisation in grazing dairy cows. Journal of Dairy Science 89: 3494-3500.

Taweel, H.Z.; Tas, B.M.; Smit, H.J.; Elgersma, A.; Dijkstra, J.; Tamminga, S. 2006. Grazing behaviour, intake, rumen function and milk production of dairy cows offered Lolium perenne containing different levels of water-soluble carbohydrates. Livestock Science 102: 33-41.

Thomas, T.A. 1977. An automated procedure for the determination of soluble carbohydrates in herbage. Journal of the Science of Food and Agriculture 28: 639-642.

Woodford, K.B.; Nicol, A.M. 2004. A re-assessment of the stock unit system. Ministry of Agriculture Information Paper No. 2005/02. 
